\title{
Self Awareness Dan Perilaku Faking Pada Kegiatan Wawancara Kerja Karyawan
}

\author{
Mukhaira El Akmal, Martha Dewi Kasih Riang Waruwu, Yuninka Cicilia Br. Sinaga, Jecika \\ Alisya, Naween \\ Fakultas Psikologi Universitas Prima Medan, Indonesia \\ Email : mukhaira.akmal@gmail.com, kasihwaruwu09@gmail.com, cicilia.yuninka@gmail.com, \\ jecikaalisya4@gmail.com, nawincreak@gmail.com
}

\begin{abstract}
This study aims to determine the description of self-awareness and faking behavior in employee job interviews. This study uses a qualitative research method with a case study approach. The main subjects in this study were 5 people with the following characteristics: employees who have just worked for less than one year. The results showed that the subject showed a different picture of self-awareness and faking behavior in several aspects. Subjects are able to understand themselves, set life and career goals, build relationships with others, build diversity values, be able to balance their own needs with job demands, and develop self-control over appropriate stimuli. Meanwhile, in faking behavior during job interviews, subjects tend to prioritize physical appearance during the interview, ability to communicate and cover up negative self-images during the interview.
\end{abstract}

Keywords: self-awareness, faking behavior, applicant behavior, job interview

\begin{abstract}
Abstrak
Penelitian ini bertujuan untuk mengetahui gambaran self-awareness dan perilaku faking pada wawancara kerja karyawan. Penelitian ini menggunakan metode penelitian kualitatif dengan pendekatan studi kasus. Subjek utama dalam penelitian ini sebanyak 5 orang dengan karakteristik sebagai berikut : pegawai yang baru bekerja dalam rentang waktu kurang dari satu tahun. Hasil penelitian menunjukkan bahwa subjek memperlihatkan gambaran self-awareness dan perilaku faking yang berbeda dalam beberapa aspek. Subyek mampu memahami diri sendiri, menyusun tujuan hidup dan karir, membangun relasi dengan orang lain, membangun nilai keberagaman, mampu menyeimbangkan kebutuhan diri sendiri dengan tuntutan pekerjaan, dan mengembangkan kontrol diri terhadap stimulus yang tepat. Sementara itu, dalam perilaku faking saat wawancara kerja, subyek cenderung mengutamakan penampilan fisik saat wawancara, kemampuan saat berkomunikasi dan menutupi citra negatif diri saat wawancaraberlangsung.
\end{abstract}

Kata Kunci : self-awareness, faking behavior, applicant behavior, wawancara kerja

\section{Pendahuluan}

Pekerjaan dan lapangan pekerjaan adalah dua hal yang selalu menjadi permasalahan sejak dulu. Angka kelulusan siswa SMA dan Mahasiswa Perguruan Tinggi semakin lama kian meningkat menyebabkan naiknya jumlah pelamar pekerjaan. Sedangkan lapangan pekerjaan tidak dapat menampung semua pelamar. Dilansir dari Kompas.com, Badan Kepegawaian Negara (BKN) mengatakan jumlah pelamar CPNS hingga 23 November 2019 adalah sebanyak 4.550.318. Sementara itu, sebanyak 3.137.844 telah mengisi formulir dan 2 juta orang sudah submit lamaran. Sumber lain dari Republika.co.id-Jakarta, perusahaan penyedia informasi lowongan kerja online jobstreet.com menyatakan, rata-rata 110 pelamar bisa memperebutkan satu lowongan pekerjaan. Bahkan, lowongan yang ditawarkan dalam satu iklan termasuk jobstreet.com bisa diperebutkan hingga 2 ribu pelamar. Hal-hal tersebut dapat menjadi contoh bukti bahwa persaingan kerja semakin ketat. Dengan alasan itu, calon pelamar pada akhirnya merasa kesulitan untuk bisa mendapatkan pekerjaan di sebuah perusahaan.

Perusahaan menurut Undang-Undang No. 13 Tahun 2003 Pasal 1 Ayat 6 adalah setiap bentuk usaha yang berbadan hukum atau tidak, miliki orang perseorangan, milik persekutuan atau milik badan hukum, baik milik swasta maupun milik negara yang mempekerjakan pekerja/buruh dengan membayar upah atau imbalan dalam bentuk lain. Usaha-usaha sosial dan usaha-usaha lain yang memiliki pengurus dan mempekerjakan orang lain dengan membayar upah atau imbalan dalam bentuk lain. Sedangkan menurut Sumarni (1997) perusahaan adalah sebuah unit kegiatan produksi 
yang mengolah sumber daya ekonomi untuk menyediakan barang dan jasa bagi masyarakat dengan tujuan memperoleh keuntungan dan memuaskan kebutuhan masyarakat. Dari pengertian tersebut, dapat disimpulkan bahwa perusahaan adalah sebuah tempat dimana sekumpulan orang bekerja secara jasa maupun produksi untuk menghasilkan sesuatu bagi masyarakat serta memperoleh laba.

Perusahaan tidak dapat berjalan jika tidak ada sumber daya manusia (SDM) yang mencukupi. Perusahaan membutuhkan orang-orang sesuai kualifikasi yang mereka butuhkan agar tujuan perusahaan dapat terpenuhi. Berdasarkan alasan tersebut, perusahaan membuat program rekrutmen dan juga seleksi agar menemukan kandidat terbaik. Ketatnya persaingan dalam dunia kerja membuat banyaknya calon karyawan sadar akan kompetisi yang dihadapi. Kompetisi tersebut tentunya dimulai ketika suatu perusahaan melangsungkan proses rekrutmen dan seleksi. Untuk proses rekrutmen dan seleksi calon karyawan, perusahaan melaksanakannya secara bertahap mulai dari menyebarkan informasi soal rekrutmen, seleksi administrasi, tes kemampuan, wawancara, lalu penawaran kerja. Menurut Cascio (dalam Naibaho, 2012) mengatakan bahwa proses rekrutmen karyawan adalah suatu proses penerimaan calon tenaga kerja untuk memenuhi kebutuhan pada suatu unit kerja dalam suatu organisasi atau perusahaan dan seleksi calon tenaga kerja yang merupakan proses pemilihan calon tenaga kerja yang paling memenuhi syarat untuk mengisi lowongan pekerjaan.

Pelaksanaan proses rekrutmen, seleksi dan penempatan karyawan jika dilakukan dengan cara yang tepat, jujur, cermat, dan objektif maka akan dipastikan mendapatkan calon karyawan yang berkualitas (Pusparani, 2018). Dari semua alat bantu seleksi yang dipergunakan untuk membedakan para calon karyawan, wawancara tetap merupakan metode yang paling umum. Schmidt dan Hunter (dalam Law, dkk., 2016) mengatakan bahwa ada banyak metode berbeda yang digunakan untuk menyeleksi karyawan dan telah menunjukkan validitas prediktif seperti pengujian kemampuan mental umum, pengujian kepribadian, dan sampel pekerjaan namun Huffcutt dan Culbertson (dalam Law, dkk., 2016) menegaskan bahwa kegiatan wawancara telah diadopsi hampir secara universal dalam membuat keputusan perekrutan. Kandidat yang tidak melakukan wawancara pekerjaan dengan baik kemungkinan akan digugurkan tanpa memperhatikan pengalaman, skor tes, atau surat rekomendasi. Selain itu, para kandidat dapat diberi peringkat lebih rendah untuk sesuatu yang sepele seperti noda pada wajah mereka, sebagaimana yang ditemukan dalam penelitian terbaru (Robbins \& Judge, 2015). Hal ini menegaskan bahwa penguji hanya akan menyaring kandidat terbaik bagi perusahaan.

Wawancara merupakan pertemuan dua orang untuk bertukar informasi dan ide melalui tanya jawab, sehingga dapat dikontruksikan makna dalam suatu topik tertentu (Sugiyono, 2013). Sedangkan wawancara kerja adalah salah satu kegiatan dalam proses rekrutmen yang digunakan oleh perusahaan untuk menyaring atau memilih calon karyawan atau pegawai terbaik dari pelamar yang ada (Purwanto, 2008). Wawancara dalam proses rekrutmen dan seleksi merupakan sebuah tahapan penilaian calon karyawan yang melibatkan pewawancara dari sebuah perusahaan untuk menilai lebih lanjut apakah calon karyawan diterima atau ditolak. Kesiapan tersebut pada akhirnya muncul pada calon karyawan karena mereka menyadari bahwa kegiatan seleksi dan rekrutmen adalah kegiatan yang amat kompetitif, mengingat bahwa sebuah perusahaan hanya memilih pelamar terbaik.

Wawancara sebagai tahap krusial dalam sebuah seleksi dan wawancara akhirnya menimbulkan kesadaran pada calon karyawan yang akan melamar ke dalam suatu perusahaan. Kesadaran tersebut membentuk calon karyawan agar mempersiapkan dirinya untuk sebuah tantangan. Rachman (2016) mengatakan bahwa self awareness adalah kemampuan melihat pola pikir serta perilaku kita yang berada pada ketidaksadaran dan mengangkatnya ke alam sadar. Selanjutnya, menurut Goleman (1996) menjelaskan bahwa, kesadaran diri adalah perhatian terus menerus terhadap batin seseorang, merefleksikan diri, pikiran mengamati dan menggali pengalaman, termasuk emosi.

Salah satu kendala potensial untuk keberhasilan wawancara adalah manajemen kesan (IM). Taktik IM adalah strategi khusus yang digunakan calon pelamar untuk memanipulasi gambaran diri yang mereka proyeksikan kepada pewawancara (Law, dkk., 2016). Maka dalam proses ini, tidak dapat dipungkiri bahwa calon karyawan akan melakukan perilaku berpura-pura (faking behavior) agar dapat terlihat meyakinkan. Faking behavior adalah respon yang disengaja terhadap suatu ukuran kepribadian yang tidak sesuai dengan citra dirinya yang sebenarnya (Kiefer \& Benit, 2016). Selain itu, Pelamar yang berpura-pura merepresentasikan informasi selama proses seleksi secara keliru dan menjadi ancaman terhadap kegunaan berbagai alat dalam seleksi (Roulin \& Krings, 2016).

Terkait kondisi karyawan yang telah dijelaskan di atas, Ron Friedman, sebagai psikolog sosial mengungkapkan $81 \%$ pelamar berbohong saat wawancara kerja. Dengan mengajukan pertanyaan 
tentang masalah sulit yang pernah dihadapi pelamar dan bagaimana cara menyelesaikannya, maka dapat diketahui apakah pelamar adalah orang-orang yang benar-benar mengambil adil dan menemukan solusi atau sebaliknya. Orang yang benar dapat menyelesaikan masalah tahu persis bagaimana menyelesaikannya dan detail kecilnya (TribunJogja.com).

Penelitian yang dilakukan oleh Johnson, dkk., (2005) mengatakan bahwa efektivitas penipuan berkorelasi dengan self-awareness yang lebih besar. Ditemukan bahwa awareness seseorang mengenai pikiran dan perasaan sendiri dapat memprediksikan kemampuannya untukD faking. Terdapat fakta yang menyatakan bahwa diri dan theory of mind (ToM) berkaitan. ToM dapat dikonseptualisasikan sebagai kemampuan untuk membaca pikiran atau menguraikan apa yang dipikirkan orang lain berdasarkan pemikiran sendiri. Lebih lanjut, temuan ini konsisten dengan gagasan bahwa satu manfaat evolusi yang diperoleh dari self-awareness adalah kemampuan untuk faking. Beberapa manfaat faking diantaranya untuk mempertahankan kesan baik pada orang lain, menghindari hukuman, dan mempertahankan hubungan sosial yang positif.

Calon karyawan yang melakukan faking behavior jelas akan membuat hasil wawancara menjadi keliru, karena ada bagian yang ditutupi atau tidak disampaikan dengan secara tepat. Padahal harapan perusahaan kegiatan wawancara sendiri dapat digunakan untuk mengetahui apakah calon pelamar tersebut adalah orang yang tepat untuk direkrut bekerja sama dalam perusahaan. Hal tersebut membuat peneliti tertarik untuk meneliti self awereness dan faking behavior pada kegiatan wawancara kerja karyawan.

Tujuan dari penelitian ini adalah untuk mengetahui secara mendalam bagaimana self awareness dan faking behavior yang dilakukan oleh karyawan yang mengikuti wawancara kerja. Diharapkan penelitian ini dapat menambah ilmu dalam pembelajaran mengenai self-awareness dan perilaku faking pada calon karyawan. Selain itu, hasil penelitian ini juga diharapkan dapat memberikan manfaat bagi perkembangan ilmu - ilmu psikologi, khususnya di bidang rekrutmen dan seleksi. Hasil penelitian ini diharapkan dapat memberikan informasi serta manfaat untuk studi lebih lanjut kepada perusahaan agar mengetahui adanya perilaku faking pada saat wawancara kerja di perusahaan. Dan penelitian ini diharapkan mampu memberikan manfaat ilmu baru bagi peneliti yang kemudian dapat diaplikasikan dalam dunia kerja.

\section{Metode Penelitian}

Menurut Kirk dan Miller (dalam Anggito \& Setiawan, 2018) penelitian kualitatif adalah tradisi tertentu dalam ilmu pengetahuan sosial yang secara fundamental bergantung dari pengamatan pada manusia baik dalam kawasannya maupun dalam peristilahannya. Pada penelitian ini, prosedur pengambilan subjek dilakukan dengan menggunakan teknik purposive sampling (sampel bertujuan), sebagaimana yang dikemukakan oleh Arikunto (2013) bahwa pengambilan sampel dilakukan dengan cara mengambil subjek bukan didasarkan atas strata, random atau daerah, tetapi didasarkan atas adanya tujuan tertentu. Peneliti mempertimbangkan untuk mencari subjek yang sesuai dengan tujuan penelitian, memiliki waktu luang dan bersedia diwawancarai menjadi informan. Karakteristik sampel dalam penelitian ini adalah karyawan yang bekerja disalah satu perusahaan swasta Medan dimana sampel yang akan digunakan dalam penelitian ini sebanyak 5 orang.

Sugiyono (2017) mengatakan bahwa dalam penelitian kualitatif, pengumpulan data dilakukan pada natural setting (kondisi yang alamiah), sumber data primer dan teknik pengumpulan data lebih banyak pada observasi berperan serta (participant observation), wawancara mendalam (in depth interview), dan dokumentasi. Menurut Swarjana (2012) bahwa metode observasi merupakan metode yang paling umum digunakan terutama yang terkait dengan ilmu-ilmu perilaku. Kemudian lebih ditekankan oleh Ni'matuzahroh dan Prasetyaningrum (2018) mengatakan bahwa observasi adalah pengamatan terhadap perilaku seseorang pada situasi tertentu. Pengamatan tersebut bertujuan untuk melakukan asesmen terhadap permasalahan. Menurut Fitrah dan Luthfiyah (2017) Salah satu metode pengumpulan data adalah dengan jalan wawancara, yaitu mendapatkan informasi dengan cara bertanya langsung dengan responden, dimana dua orang atau lebih bertatap muka mendengarkankan secara langsung informasi atau keterangan, sehingga dapat dikonstruksikan makna dalam suatu topik tertentu (Sugiyono, 2017). Hadari (dalam Fitrah \& Luthfiyah, 2017) wawancara pada hakikatnya merupakan kegiatan yang dilakukan seorang peneliti untuk memperoleh pemahaman secara holistik mengenai perspektif seseoramg terhadap isu, tema, atau topik tertentu. 
Pelaksanaan pengumpulan data ini juga melibatkan berbagai aktivitas pendukung lainnya, seperti menciptakan rapport, pemilihan informan, pencatatan data atau informasi hasil pengumpulan data. Pada dasarnya kegunaan data (setelah diolah dan dianalisis) ialah sebagai dasar yang objektif didalam proses pembuatan keputusan-keputusan atau kebijakan dalam rangka untuk memecahkan persoalan oleh pengambil keputusan (Situmorang, 2010). Peneliti melakukan penelitian secara bertahap yaitu yang pertama, peneliti melakukan persiapan dengan menyiapkan paradigma tentang penelitian yang akan diteliti. Setelah menyiapkan paradigma penelitian, peneliti kemudian akan menyusun daftar pertanyaan wawancara terkait aspek penelitian yang akan ditanyakan kepada subjek.

Langkah pertama yang dilakukan sebelum analisis data adalah membubuhkan kode-kode pada materi yang diperoleh. Koding dimaksudkan untuk dapat mengorganisasi dan mensistematisasi data secara lengkap dan mendetail sehingga data dapat memunculkan gambaran tentang topik yang dipelajari. Semua peneliti dalam penelitian kualitatif menganggap tahap koding sebagai tahap yang penting, meskipun peneliti yang satu dan yang lain memberikan usulan prosedur yang tidak sepenuhnya sama (Poerwandari, 2013). Secara praktis dan efektif, langkah awal koding dapat dilakukan melalui: pertama, peneliti menyusun transkripsi verbatim (kata demi kata). Hal ini memudahkan peneliti membubuhkan kode-kode atau catatan-catatan tertentu di atas transkrip tersebut. Kedua, peneliti secara urut dan continue melakukan penomoran pada baris-baris transkrip tertentu. Ketiga, peneliti memberikan nama untuk masing-masing berkas dengan kode tertentu, serta memberi tanggal di tiap berkas.

Untuk tahap melaksanakan penelitian, peneliti akan membuat kesepakatan dengan subjek mengenai waktu dan tempat guna melaksanakan wawancara mendalam atau in depth interview mengenai selfawareness dan perilaku faking pada calon karyawan. Metode kualitatif lebih tepat menggunakan istilah autentisitas dari pada validitas. Karena autentisitas lebih berarti memberikan deskripsi, keterangan, informasi (account) yang adil (fair) dan jujur. Harus dijamin bahwa hasil yang diperoleh dan interpretasinya adalah tepat. Interpretasi harus berdasarkan informasi yang disampaikan oleh partisipan dan bukan karangan peneliti sendiri (Raco, 2010).

Adapun penelitian kualitatif, mengganggap hipotesa tidak begitu diperlukan, sebab peneliti akan berfungsi sebagai instrumen penelitian dalam interaksi dan relasinya dengan informan pada saat mengumpulkan data kualitatif, berdasarkan latar alami (natural setting), dan selalu terkait dalam konteksnya (Yusuf, 2017).

Wawancara untuk pengambilan data pada penelitian ini dilakukan 30 Juni - 24 Juli 2020 melalui janji temu dengan partisipan yang bersedia ditemui dan wawancara virtual dengan partisipan yang berhalangan. Subjek dalam penelitian ini adalah 5 orang karyawan dengan karakteristik sebagai berikut: Karyawan yang baru bekeja kurang dari 1 tahun. Bekerja di perusahaan yang sama. Memiliki latar belakang pendidikan yang berbeda-beda.

\section{Hasil dan Pembahasan}

Hasil pada penelitian ini membahas gambaran aspek self-awareness ataupun dimensi perilaku faking yang terdapat pada karyawaan saat wawancara kerja. Berdasarkan hasil wawancara, di bawah ini akan dijelaskan mengenai perbedaan ataupun persaamaan karakteristik yang dimiliki oleh ke-5 Subjek tentang self-awareness dan perilaku faking.

\section{Self-awareness}

Menurut Glenn (2008), ciri-ciri individu yang mempunyai self-awareness yang baik adalah sebagai berikut: Memahami diri sendiri

Analisis pada subjek I, II, dan V sama-sama menunjukkan reaksi yang sama dalam mengambil keputusan sehari-hari yaitu mencoba untuk mempertimbangkan dengan orang lain yang sudah berpengalaman agar mendapatkan solusi. Pandangan subjek III dalam mengambil keputusan seharihari tidak mempertimbangkan banyak hal dan lebih memikirkan masalah dengan sendiri. Sedangkan subjek IV mengambil keputusan dengan sendiri dalam sehari-hari dikarenakan subjek pernah menyesal dengan keputusan hasil diskusi dengan orang lain.

Menyusun tujuan hidup dan karir dengan tepat

Dalam merencanakan tujuan hidup dan karir analisis subjek II dan V memiliki kesamaan pandangan yaitu ingin memiliki usaha sendiri dan mengalami peningkatan dibidang karir. Analisis subjek I memiliki tujuan karir untuk mendapatkan jabatan yang lebih tinggi dan tujuan hidup subjek agar bisa 
naik haji. Sedangkan subjek III memiliki tujuan karir menjadi seorang motivator dan membahagiakan kedua orang tua. Dan subjek IV mengatakan bahwa tujuan hidup dan karir dalam hidupnya menyerahkan segalanya terhadap Tuhan Yang Esa.

Membangun relasi dengan orang lain

Dalam hubungan interpersonal kelima subjek pernah berkonflik dengan sesama karyawan. Untuk membangun relasi yang baik kelima subjek membangun dan mengembangkan hubungan interpersonal dengan komunikasi. Subjek I, II dan III membangun relasi dengan menjalin hubungan yang akrab sedangkan subjek IV dan $\mathrm{V}$ dengan mempelajari karakteristik orang lain dan menempatkan diri dalam lingkungan.

Membangun nilai-nilai keberagamaan.

Kelima subjek dalam membangun nilai agama dilandasi dengan keagamaan. dan kelima subjek terbiasa berada di lingkungan yang beragam dan hidup dalam perbedaan. Semua subjek setuju dengan toleransi yang harus dipupuk agar semua orang dapat hidup berdampingan dalam kedamaian. Mampu menyeimbangkan antara tuntutan kebutuhan diri dengan kebutuhan komunitas.

Pada saat melamar pekerjaan diperusahaan kelima subjek tidak benar-benar memahami kebutuhan perusahaan. Tetapi kelima subjek mengaku mampu beradaptasi dan menyeimbangkan kebutuhan pribadi dengan kebutuhan perusahaan pada saat itu. Subjek I, II dan IV mampu menyalurkan kemampuannya pada bidang pemasaran dengan keahlian komunikasi. Subjek III memilih meninggalkan hobby demi fokus pada pekerjaannya, Sedangkan subjek V menerangkan bahwa ia akan mempersiapkan diri dengan maksimal dan mempelajari dengan baik pekerjaannya agar tampil maksimal di depan klien.

Mengembangkan kontrol diri terhadap stimulus dengan tepat.

Dalam mengontrol diri, subjek I dan V memiliki kesamaan yaitu cenderung tidak bertindak secara emosional dan berbicara terang-terangan tentang kondisi yang dirasa membuat tidak nyaman, akan tetapi keduanya mengaku bukan individu pendendam. Sedangkan subjek II, III, dan IV memiliki kontrol diri yang berbanding terbalik dengan subjek I dan $\mathrm{V}$, yaitu memilih mengevaluasi permasalahan, menahan emosi terlebih dahulu dan berdiskusi secara baik-baik.

\section{Perilaku faking}

Levashina \& Campion (dalam a model of faking likelihood in the employment interview, 2006) menyebutkan 3 dimensi faking terjadi, yaitu:

Kapasitas untuk faking

Kelima Subjek setuju bahwa penampilan meliputi pakaian dan kerapihan saat wawancara adalah hal yang sangat perlu dipersiapkan. Dalam hal ini, Subjek I mengatakan bahwa satu-satunya persiapan wawancara yang dilakukannya adalah dengan memperhatikan penampilan. Subjek II membuktikannya dengan tidur yang cukup, dan memastikan bahwa bajunya terlihat rapih pada saat wawancara, Subjek III dan V menyiapkannya dengan membeli sepatu baru dan pakaian baru agar memiliki penampilan lebih baik, sedangkan Subjek IV tidak hanya mempersiapkan penampilan tapi juga kepercayaan diri agar saat wawancara, subjek terlihat lebih meyakinkan.

Kesediaan untuk faking (Ciri-ciri kepribadian)

Penelitian tentang penipuan dan faking dalam pengujian kepribadian telah menunjukkan bahwa orang yang tinggi dalam Machiavellianisme, pemantauan diri, kebutuhan akan persetujuan, dan kesadaran diri publik lebih berhasil dalam mengelola kesan mereka daripada mereka yang rendah sifat ini. Subjek I dan III ditemukan tidak membuat usaha apapun untuk memberi kesan yang baik kepada pewawancara. Subjek II, IV dan V mengaku hanya memunculkan sikap serta komunikasi yang baik sebagai upaya menutupi citra negatif yang dimiliki untuk menghindari kecacatan wawancara dirinya.

\section{Integritas}

Dalam analisa data wawancara, didapati Subjek IV mengaku merasa wajar jika ditemukan seseorang melakukan kebohongan saat wawancara kerja karena menurutnya itu adalah usaha yang dilakukan agar orang tersebut mendapatkan pekerjaan. Sedangkan, Subjek I, II, III dan V memiliki pandangan yang sebaliknya. Bagi keempat subjek, kecurangan ataupun kebohongan yang dilakukan saat wawancara kerja akan merugikan diri sendiri. 
Berdasarkan hasil penelitian, didapat bahwa masing-masing subjek memiliki cara masing-masing dalam pengambilan keputusan. Hal ini dapat terjadi karena perbedaan latar belakang keluarga dan pendidikan. Hal ini sejalan dengan pernyataan Arroba (1998) yang mengatakan bahwa salah satu faktor dalam pengambilan keputusan adalah tingkat pendidikan. Kotler (2003) juga berpendapat bahwa salah satu faktor dalam pengambilan keputusan adalah faktor sosial yang meliputi kelompok acuan, keluarga, peran, dan status.

Seluruh subjek dalam caranya membangun relasi dengan orang lain menunjukkan bahwa komunikasi adalah hal yang paling penting dalam membangun dan menjaga hubungan harmonis dengan orang di sekitar mereka. Hal ini sejalan dengan bentuk self-awareness simbolik yaitu kemampuan seseorang untuk membentuk sebuah konsep abstrak dari diri melalui bahasa,kemampuan seseorang untuk berkomunikasi,menjalin hubungan menentukan tujuan, mengevaluasi hasil dan membentuk sikap yang berhubungan dengan diri dan membelanya terhadap komunikasi yang mengancam (Baron dan Bryn 2005). Untuk memahami dan menghargai nilai keberagaman, seluruh subjek mampu menunjukkan rasa hormat meskipun mereka tidak perlu berpindah keyakinan. Hal ini senada dengan apa yang disampaikan oleh Casram (2016) bahwa toleransi tidak berarti bahwa seseorang yang telah mempunyai keyakinan kemudian berpindah atau merubah keyakinannya untuk mengikuti dan berbaur dengan keyakinan atau peribadatan agama-agama lainnya (sinkretisme).

Dalam gambaran perilaku faking subjek pada penelitian ini, didapatkan informasi bahwa penampilan fisik adalah hal yang paling penting dalam persiapan wawancara agar tampil professional dan meyakinkan. Hal ini didukung dengan pernyataan yang dikemukakan oleh Butlerdan Roesel (dalam Slepian, dkk., 2015) yang mengatakan bahwa mengenakan pakaian formal dikaitkan dengan persepsi lebih profesional tetapi juga kurang dapat didekati. Selain penampilan, usaha subjek untuk membuat pewawancara terkesan adalah dengan menunjukkan kemampuan berkomunikasi. Delery dan Kacmar (dalam Bourdage, dkk, 2017) menyampaikanbahwa dalam hal ini subjek menggunakan praktek IM (Impression Management) berupa karakteristik seperti keterampilan atau pengalaman komunikasi kemampuan berkomunikasi juga amat mempengaruhi impression management (IM) selama wawancara berlangsung.

\section{Kesimpulan}

Berdasarkan data penelitian dan rumusan masalah yang telah disampaikan, maka kesimpulan dari penelitian ini adalah tiap pelamar memiliki gambaran self-awareness dan perilaku faking yang tidak jauh berbeda. Tiap pelamar dapat mengambil keputusan yang terbaik untuk diri mereka, membuat rencana untuk mencapai tujuan hidup dan karir, membangun komunikasi dengan orang lain untuk menjaga hubungan harmonis, memiliki pandangan positif tentang keberagaman di lingkungan mereka, dan dapat memprioritaskan tuntutan pekerjaan dengan meninggalkan kebiasaan lama. Pada perilaku faking, ditemukan bahwa subjek cenderung mengutamakan penampilan pada saat wawancara kerja, mencari tahu gambaran pekerjaan dan bagaimana harus bersikap saat wawancara kerja. Saat wawancara berlangsung, pelamar akan menutupi hal-hal negatif yang akan merusak citra dirinya dan lebih menunjukkan kemampuannya. Kebohongan saat wawancara dianggap merugikan perusahaan dan pelamar itu sendiri, namun dirasa wajar karena itu merupakan salah satu bentuk usaha agar diterima bekerja.

Adapun saran yang dapat disampaikan dalam penelitian ini kepada para interviewee yang sedang melaksanakan wawancara kerja agar tidak merekayasa potensi dan kemampuan mereka yang pada akhirnya menyulitkan interviewee dalam berkontribusi dan mengembangkan diri di perusahaan yang menerima mereka bekerja. Bagi para interviewer di perusahaan diharapkan untuk lebih cermat dan hati-hati dalam memberikan penilaian kepada pelamar sehingga bisa memberikan keputusan yang tepat dalam menyeleksi dan menempatkan karyawan. Terakhir, untuk peneliti selanjutnya yang akan meneliti tentang faking behavior agar dapat meneliti variabel ini dengan dikaitkan dengan variabel dan karakteristik yang berbeda.

\section{Ucapan Terimakasih}

Terima kasih kepada pihak perusahaan yang telah mengizinkan peneliti untuk dapat melakukan penelitian, dan juga kepada subjek dalam penelitian ini yang telah memberikan waktu luang untuk melengkapi data dalam penelitian ini. Juga Kepada orang tua kami yang selalu memberikan 
dukungan, motivasi dan doa yang selalu menyertai peneliti dan kepada rekan sesama peneliti yang telah memberikan waktu, tenaga, dan pikiran guna melengkapi penelitian ini.

\section{Daftar Rujukan}

[1] A. N. Dzulfaroh, "Data terkini CPNS 2019: jumlah pelamar 2,2 juta, top 10 instansi," https://www.kompas.com/tren/read/2019/1 1/24/093605865/data-terkini-cpns-2019-jumlah-pelamar-22juta-top-10-instansi. Kompas.com, 2019.

[2] L. Sulistyawati and D. Murdaningsih, "Rata-rata 110 pelamar bisa memperebutkan satu lowongan pekerjaan," https://m.republika.co.id/amp/nl3c9q. Republika.co.id, 2015.

[3] UU RI, "Undang-Undang No. 13 tentang ketenagakerjaan Republik Indonesia." 2003.

[4] M. Sumarni, Pemasaran. Yogyakarta: Liberty, 1997.

[5] H. Naibaho, "Analisis Pengaruh Rekrutmen dan Seleksi Terhadap Kinerja Karyawan Di Indonesia," J. Eksek., vol. 9, no. 2, pp. 583-596, 2012.

[6] D. Pusparani, "Analisis Proses Rekrutmen Dan Seleksi Tenaga Kesehatan Tim Nusantara Sehat Dalam Program Nusantara Sehat Kementerian Kesehatan Republik Indonesia," J. Kesehat. Masy., vol. 4, no. 4, pp. 60-69, 2016.

[7] S. J. Law, J. Bourdage, and T. A. O'Neill, "To fake or not to fake: Antecedents to interview faking, warning instructions, and its impact on applicant reactions," Front. Psychol., vol. 7, no. NOV, pp. 1-13, 2016, doi: 10.3389/fpsyg.2016.01771.

[8] S. P. Robbins, F. Sirait, R. Saraswati, and T. A. Judge, Perilaku Organisasi, Ed. 16. Jakarta: Salemba Empat, 2015.

[9] Sugiyo, Metode penelitian pendidikan pendekatan kuantitatif, kualitatif, dan R\&D. Bandung: Alfabeta, 2013.

[10] Purwanto, Metode Penelitian Kualitatif. Yogyakarta: Pustaka Belajar, 2008.

[11] E. Rachman, Sukses Wawas Diri. Jakarta: Gramedia Pustaka utama, 2016.

[12] D. Goleman, Kecerdasan Emosional. Jakarta: PT Gramedia Pustaka Utama, 2007.

[13] M. Techniques, C. Kiefer, and N. Benit, "What is Applicant Faking Behavior? A Review on the Current State of Theory and Modeling Techniques," J. Eur. Psychol. Students, vol. 7, no. 1, pp. 9-19, 2016, doi: 10.5334/jeps.345.

[14] N. Roulin and F. Krings, "When Winning is Everything: The Relationship between Competitive Worldviews and Job Applicant Faking," Appl. Psychol., vol. 65, no. 4, pp. 643-670, 2016, doi: 10.1111/apps.12072.

[15] K. Muhammad, "81 persen pelamar berbohong saat wawancara kerja, pertanyaan ini bisa membongkarnya," https://jogja.tribunnews.com/2019/12/13/81-persen-pelamar-berbohong-saatwawancara-kerja-pertanyaan-ini-bisamembongkarnya. Tribun Jogja, 2019.

[16] A. K. Johnson et al., "Me, myself, and lie: The role of self-awareness in deception," Pers. Individ. Dif., vol. 38, no. 8, pp. 1847-1853, 2005, doi: 10.1016/j.paid.2004.11.013.

[17] A. Anggito and J. Setiawan, Metodologi Penelitian Kualitatif. Jawa Barat: CV Jejak, 2018.

[18] S. Arikunto, Prosedur penelitian (suatu pendekatan praktik). Jakarta: PT. Rineka Cipta, 2013.

[19] Sugiyono, Metode penelitian pendidikan pendekatan kuantitatif, kualitatif, dan $R \& D$. Bandung: Alfabeta, 2017.

[20] I. K. Swarjana, Metodologi penelitian kesehatan. Yogyakarta: Andi Offset, 2012.

[21] S. Ni'matuzahroh and S. Prasetyaningrum, Observasi: teori dan aplikasi dalam psikologi. Malang: Universitas Muhammadiah Malang, 2018.

[22] M. Fitrah and Luthfiyah, Metodologi Penelitian; Penelitian Kualitatif, Tindakan Kelas \& Studi Kasus. Jawa Barat: CV Jejak, 2017.

[23] P. Ginting and S. H. Situmorang, Analisis data untuk riset manajemen dan bisnis. Medan: USU Press, 2010.

[24] E. K. Poerwandari, Pendekatan kualitatif untuk penelitian perilaku manusia. Depok: Perfecta, 2013.

[25] A. M. Yusuf, Metode penelitian: kuantitatif, kualitatif \& penelitian gabungan, Ed. 1. Jakarta: Kencana, 2017.

[26] J. Levashina and M. A. Campion, "A Model of Faking Likelihood in the Employment Interview," vol. 14, no. 4, pp. 1-30, 2011, [Online]. Available: papers2://publication/uuid/A96F0D0E-C59B-4A4A9495-11214DAB184A.

[27] K. L. Harris and R. Nibler, "Decision making by Chinese and U.S. students," J. Soc. Psychol., vol. 138, no. 1, pp. 102-114, 1998, doi: 10.1080/00224549809600358.

[28] K. Philip, Manajemen Pemasaran, Ed. 11. Jakarta: PT. Indeks, 2003. 
[29] R. A. Baron and D. Bryne, Psikologi Sosial : jilid 2, Ed. 10. Jakarta: Erlangga, 2005.

[30] C. Casram, "Membangun Sikap Toleransi Beragama dalam Masyarakat Plural," Wawasan J. Ilm. Agama dan Sos. Budaya, vol. 1, no. 2, pp. 187-198, 2016, doi: 10.15575/jw.v1i2.588.

[31] M. L. Slepian, S. N. Ferber, J. M. Gold, and A. M. Rutchick, "The Cognitive Consequences of Formal Clothing," Soc. Psychol. Personal. Sci., vol. 6, no. 6, pp. 661-668, 2015, doi: $10.1177 / 1948550615579462$.

[32] J. S. Bourdage, N. Roulin, and J. Levashina, "Editorial: Impression management and faking in job interviews," Front. Psychol., vol. 8, no. JUL, pp. 8-11, 2017, doi: 10.3389/fpsyg.2017.01294. 